\title{
Congenital Pure Red Cell Aplasia
}

National Cancer Institute

\section{Source}

National Cancer Institute. Congenital Pure Red Cell Aplasia. NCI Thesaurus. Code C61236.

An inherited condition characterized by aplasia of the erythroid series only. The white cells and platelets are not affected. Patients develop anemia usually in infancy. 